The BMJ

Cite this as: BMJ2020;371:m4299 http://dx.doi.org/10.1136/bmj.m4299 Published: 09 November 2020

\section{How can I avoid getting bored mid-career?}

Following the challenges of medical training, a long term position can lose its shine after a few years.
There are, however, lots of ways to stay interested, three experts tell Abi Rimmer

Abi Rimmer

\section{"Consider a new route"}

Neil Snowise, visiting senior lecturer at the Institute of Pharmaceutical Science at King's College, London, says, "Substantive posts are usually enjoyable for many years but this may not equate to the lifetime of a career. The challenge for many mid-career professionals is how to stay enthused and motivated.

"Diversification can help, and many doctors take on other roles to help keep them interested. Others opt to take time out or a sabbatical. These changes tend to be marginal, however, and you will still need to enjoy your core work to remain fulfilled. Furthermore, not everyone wants to take on additional roles.

"I was a senior partner in a GP partnership until my mid-40s and during that time I had diversified and held several posts outside the practice. While additional roles can provide variety, putting a lot of effort into other activities may mean that you've lost interest in the core job. I certainly had lost my enthusiasm after 21 years in the NHS.

"Subsequently I left the practice and embarked on a second medical career as a pharmaceutical physician. This role has encompassed contributing to medicine development and running international clinical trials, as well as the medical aspects of marketed medicines. More recently I've been involved in studies on real world populations. I also completed an MSc.

Pharmaceutical medicine is a diverse and rewarding speciality at the cutting edge of science and business.

“Doctors have many transferable skills that aren't confined to medical knowledge and expertise. The experiences I gained as a GP of running a small business and managing budgets and stakeholders, as well as the influencing skills I developed, have been useful in my next career.

"Changing careers is a personal choice and needs careful consideration. A portfolio career without a change to your core role may work well for some; for others, like myself, it might be time to fully embrace something different. A major change is challenging but can also be stimulating and sustaining-you only live once."

\section{"Is it really boredom?"}

Sarah Goulding, coach for doctors and GP mentor, says, "If you're feeling a certain apathy about your career, let me assure you that you aren't alone. This is something I see often: doctors who have jumped through the endless career hoops to achieve their desired goal only to find themselves asking if this is it. It's worth investing time and unhurried thought (with or without professional help) in diagnosing the root cause of your discomfort.
"Is it actually boredom you're experiencing? Positions of seniority often come with levels of complexity and responsibility for which we don't feel adequately prepared. Conversely, achieving mastery can decrease the challenge we have become accustomed to.

"Let me pose a question to you-and don't ask friends or family, you are the only person whose opinion matters here-what would make your job more interesting? Your ideas might include a new challenge, such as developing a new service which you can feel some ownership over. Or maybe you'd like to adjust your work schedule to allow more time off.

"Think about how you can do more of what brings you joy and purpose. What would your ideal look like? Spend time writing down what your entire week would contain in an ideal world-both at home and at work. What do you notice? Do you need to mix things up with a bit of variety? It might be time to re-invest in your interests outside of work to feel like a more complete human again after years of striving.

"Finally, ask yourself if it's the job. It's okay to realise that you aren't finding a role fulfilling, but having to face a fundamental change to your career path can be life changing."

\section{"Don't rush into additional roles"}

Chris McAloon, foundation programme director and consultant cardiologist, says, "When you're a trainee or, like me, a relatively new consultant, challenges come thick and fast, and it feels like there's little time to become bored.

"It's important, however, to be alert to mid-career boredom, or stagnation, and the other related challenges of taking on too much too early in your career. The paradox is that you start out in a new position and it can feel like you have the bandwidth to take on several roles and responsibilities. The time required for these roles tends to expand, making less time to dedicate to achieving the goals you had when you started the post. Taking on too much too soon can make enjoying a new role difficult.

"I was given a good piece of advice by an old mentor: apart from your main role, only take on one other major position or role every five years. The logic is that this will allow you to develop and achieve within that position without having other competing objectives.

"This rule also allows you to take on other roles in other areas during your career, which can provide variation and challenges to your core role. It also means you have time to dedicate to it, meaning you 
don't take on too much in one go. This is my career strategy to combat mid-career boredom.” 